\title{
Stem Borers (Lepidoptera: Crambidae) in Florida Rice ${ }^{1}$
}

\author{
Julien M. Beuzelin, Erik L. Roldán, Ronald H. Cherry, and Matthew T. VanWeelden²
}

\section{Introduction}

Approximately 25,000 acres of rice (Oryza sativa L.) are grown in the Everglades Agricultural Area of Florida in rotation with sugarcane (Saccharum spp. hybrids), sweet corn (Zea mays L.), and leafy vegetables (Bhadha et al. 2019). In addition to being a cash crop for growers, flooded rice provides environmental benefits to the agroecosystem, including reduction in subsidence of organic soils (Bhadha et al. 2020), improvements in soil nutrient levels (Bhadha et al. 2018), and mitigation of soil arthropod pests (Cherry et al. 1994). Insect pest management in Florida rice has focused on the rice stink bug complex, which includes Oebalus pugnax (F.), as well as Oebalus insularis Stål and Oebalus ypsilongriseus (DeGeer), which are invasive species in the continental United States exclusive to Florida (Cherry 2019; VanWeelden et al. 2020).

Stem borers (Lepidoptera: Crambidae) are pests of rice in the southern United States and might represent a threat to rice production in Florida. The following publication briefly describes stem borers and sampling methods and reports results of the first extensive survey conducted to measure their occurrence in Florida rice. This publication provides information on the pest status and management considerations for stem borers to assist Extension personnel in making recommendations and Florida rice growers in implementing sustainable insect pest management practices.

\section{Stem Borers in Rice Produced in the Southern United States}

The sugarcane borer, Diatraea saccharalis (F.), rice stalk borer, Chilo plejadellus Zincken, and Mexican rice borer, Eoreuma loftini (Dyar), are three stem borers infesting rice in the southern United States (Beuzelin et al. 2016). The three species share comparable behaviors. The adults are moths that lay eggs on rice plants. The young larvae move toward the space between the culm and leaf sheaths, on which they feed. Larvae subsequently bore into the culms, disrupting plant growth. Upon larval development completion, larvae pupate within culms, from which the adults will emerge.

Sugarcane borer (SCB) larvae have brown spots and a brown head capsule and can grow to $3 \mathrm{~cm}$ in length (Figure 1). The adults are straw colored moths with delta-shaped wings. The forewings each exhibit two parallel, relatively darker lines forming two superimposed Vs pointing toward the head of the moth (Capinera 2016). This insect is a sporadic pest of rice in Louisiana and Texas. In Florida, the SCB infests sugarcane in the southern region of the state where rice is produced (Beuzelin et al. 2019). However, the insect has historically not been considered as a pest of rice in Florida.

1. This document is ENY2071, one of a series of the Entomology and Nematology Department. Original publication date October 2021. Visit the EDIS website at https://edis.ifas.ufl.edufor the currently supported version of this publication.

2. Julien M. Beuzelin,assistant professor, Entomology and Nematology Department, UF/IFAS Everglades Research and Education Center; Ronald H. Cherry, professor, Entomology and Nematology Department, UF/IFAS Everglades Research and Education Center; Erik L. Roldán, graduate assistant, Entomology and Nematology Department; Matthew T. VanWeelden, Extension agent III, crops, UF/IFAS Extension Palm Beach County; UF/IFAS Extension, Gainesville, 32611.

The Institute of Food and Agricultural Sciences (IFAS) is an Equal Opportunity Institution authorized to provide research, educational information and other services

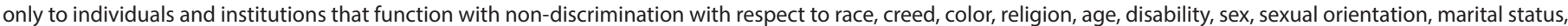

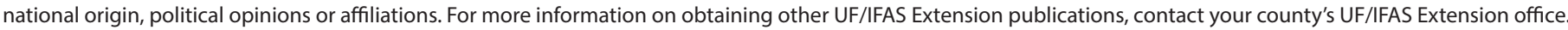
U.S. Department of Agriculture, UF/IFAS Extension Service, University of Florida, IFAS, Florida A \& M University Cooperative Extension Program, and Boards of County Commissioners Cooperating. Andra Johnson, dean for UF/IFAS Extension. 
Rice stalk borer (RSB) larvae have parallel brown stripes and a dark brown head capsule and are similar in size to SCB larvae (Figure 1). The adults resemble SCB moths; however, the wings exhibit scattered dark spots. In Louisiana and Texas rice, the RSB is a minor pest, whereas in Florida the insect has been collected only in the northern region of the state and has not been reported as pest of rice in the southern region.

Mexican rice borer (MRB) larvae have parallel purple-red stripes and a light colored head capsule (Figure 1). The adults resemble SCB moths, although they tend to be smaller and the wings do not exhibit any pattern except for a small dark dot that is sometimes present at the center of each forewing. The MRB is an invasive species that was first detected in 1980 in Texas and in 2008 in Louisiana. In Louisiana, the MRB is a serious pest of rice with yield losses exceeding 11 and 29\% in 2012 and 2013, respectively, in absence of insecticidal protection. In Florida, the MRB was first detected in 2012, and its confirmed geographical range encompasses five counties in the central region of the state. The MRB is not thought to have become established in southern Florida.

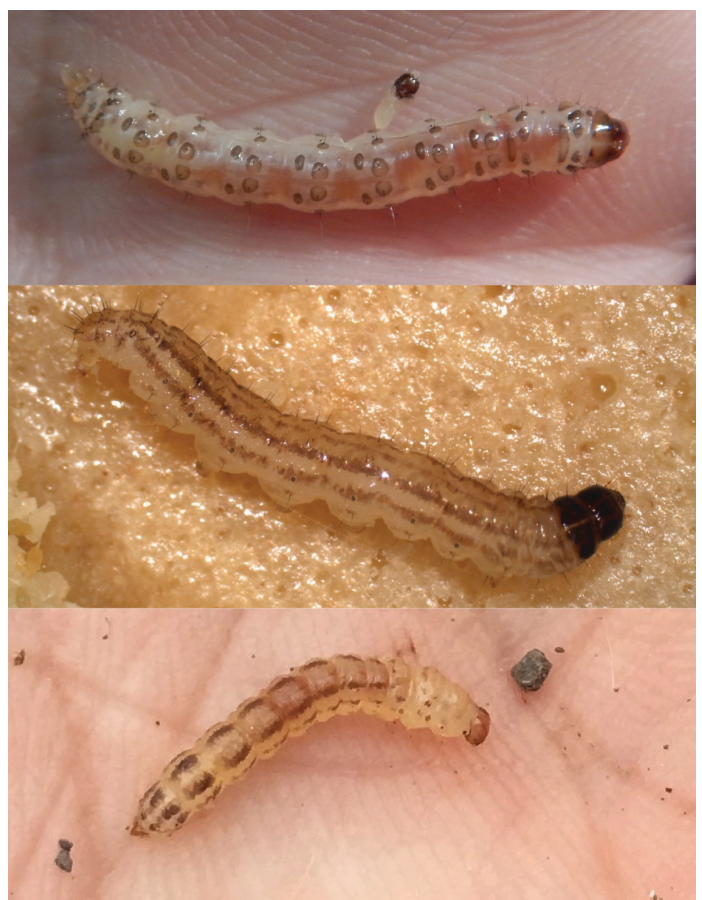

Figure 1. The sugarcane borer (top), rice stalk borer (middle), and Mexican rice borer (bottom) are three rice stem borers in the southern United States.

Credits: Julien Beuzelin, UF/IFAS for SCB and MRB, Anna Mészáros, LSU AgCenter for RSB

Beuzelin et al. (2016) provide additional details on MRB biology and management in the United States, with mentions of the SCB and RSB.

\section{Field Sampling}

Sampling for stem borers in rice fields relies on the visual observation of injury. Before heading, plant leaf sheaths should be inspected for discoloration and window paning caused by larval feeding (Figure 2). Injured plants can also exhibit deadhearts, which are dead whorl leaves resulting from injury to the growing point. After heading, plants should be inspected for injury to leaf sheaths and for whiteheads, which are white, dead panicles (Figure 3).
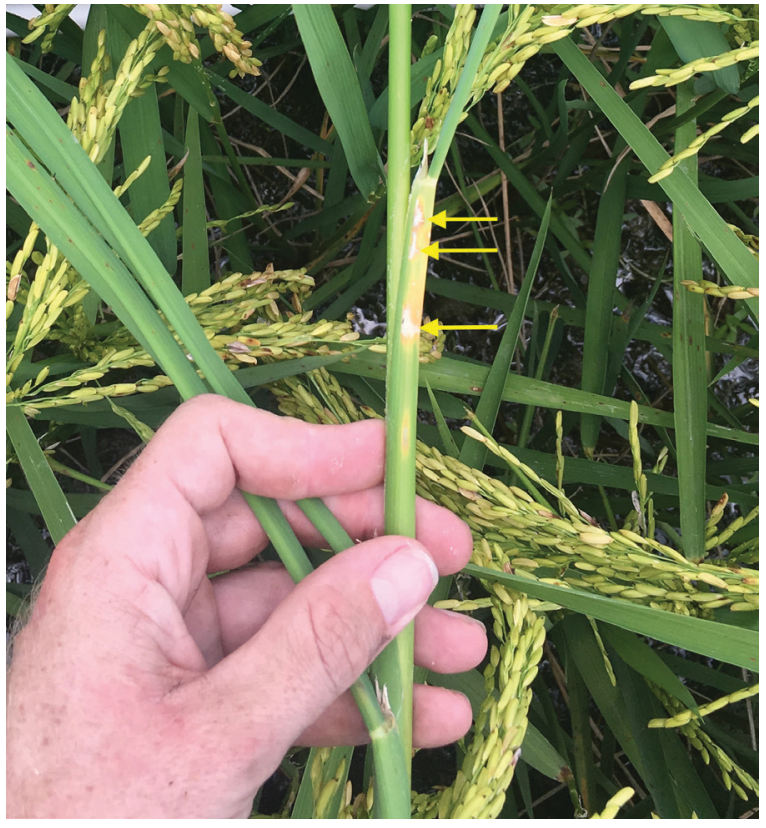

Figure 2 . Window paning caused by young sugarcane borer larvae within rice tiller leaf sheaths.

Credits: Julien Beuzelin, UF/IFAS

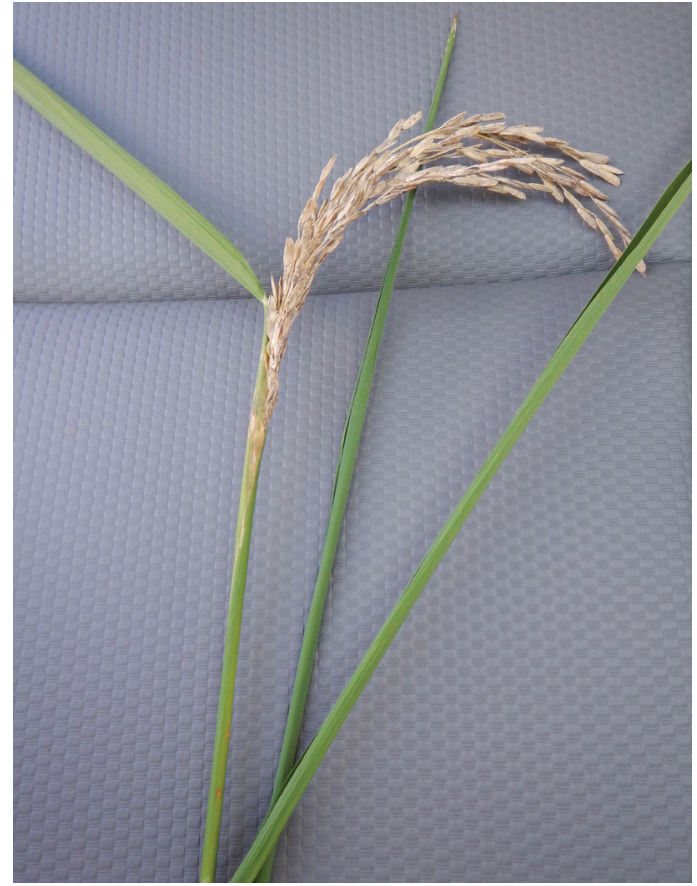

Figure 3. Whitehead caused by sugarcane borer feeding within the rice culm.

Credits: Julien Beuzelin, UF/IFAS 
Injured plants should be carefully inspected for the presence of stem borers by peeling off leaf sheaths and splitting open culms to expose larvae or pupae. Formal sampling plans for stem borers in rice have not been developed. Thus, in general, rice plants are randomly selected along a transect or a zigzag pattern throughout the field. However, using quadrats and checking all plants within a quadrat can provide an estimate of stem borer injury and infestation levels per area (Roldán et al. 2020). Field sampling can be used to determine field-specific stem borer species composition, as well as injury and infestation levels, but thresholds that would assist with management decisions have not been developed for stem borers in the southern United States.

\section{Pheromone Trap Sampling}

Lures baited with a synthetic female sex pheromone blend are commercially available for monitoring MRB adults. (One such is Luresept, available from Hercon Environmental in Emigsville, Pennsylvania). However, lures have not been developed for the SCB in spite of multiple attempts. In addition, pheromone lures have not been developed for the RSB.

For the MRB, pheromone traps have been used to detect invasive populations and to determine population trends in areas with active infestations (Wilson et al. 2017). MRB moths are generally captured in pheromone traps before a larval infestation is detected in a field, thus providing good early detection tools. In addition, trap captures exceeding 20 moths/trap/week are generally considered indicative of relatively high population levels. MRB trapping protocols recommend the use of green/yellow/white bucket traps (Figure 4) baited with the pheromone lure and containing an insecticidal strip. Traps should be placed near the edge of rice fields and hung approximately $4 \mathrm{ft}(1.2 \mathrm{~m})$ above the soil surface. Pheromone lures and insecticidal strips should be replaced every four weeks.

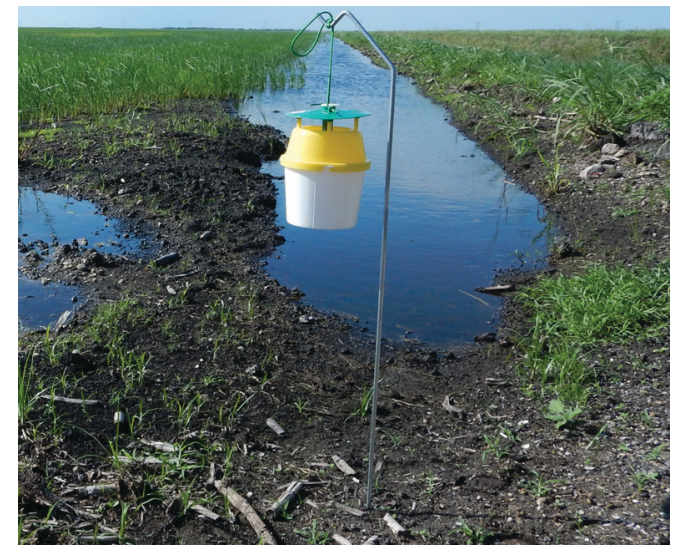

Figure 4. Pheromone trap for Mexican rice borer adult monitoring near a rice field.

Credits: Julien Beuzelin, UF/IFAS

\section{Stem Borer Injury and Infestations in Florida Rice}

A survey conducted on commercial farms in summer 2017 and 2018 used quadrat sampling along transects to determine stem borer injury and infestation levels per area (Roldán et al. 2020). In addition, MRB pheromone traps were used to monitor the presence of MRB adults. In this survey, which involved a total of 60 rice fields (Figure 5), stem borer injury was observed in eleven fields (38\%) in 2017 and nine fields (30\%) in 2018.

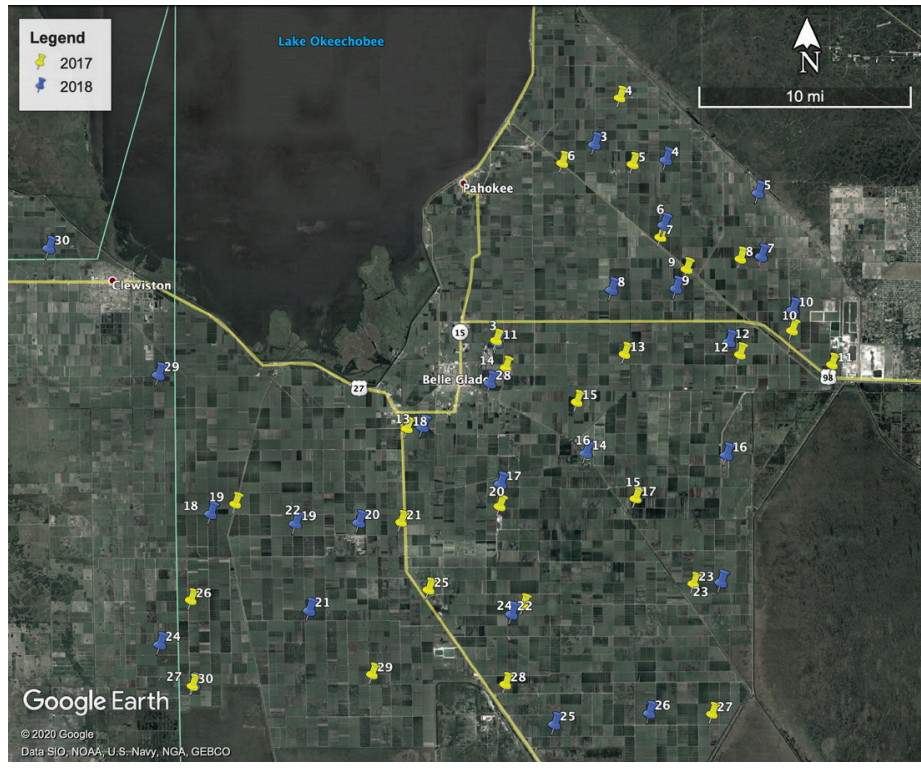

Figure 5. Locations of commercial rice fields where stem borer sampling was conducted in southern Florida in 2017 and 2018. Credits: Map obtained in Google Earth Pro for Mac OS X, Google LLC, Mountain View, CA

Only SCB larvae and pupae were observed infesting rice plants in 2017 and 2018, with infestation levels across all fields averaging 0.0006 and $0.0021 \mathrm{SCB} / \mathrm{ft}^{2}$ (0.006 and 0.023 $\mathrm{SCB} / \mathrm{m}^{2}$ ), respectively. Because parasitic wasps contribute to SCB biological control in Florida sugarcane, collected SCB larvae were maintained in the laboratory to monitor for the potential emergence of wasps. The parasitic wasp Alabagrus stigma emerged from $33 \%$ and $40 \%$ of all SCB collected in 2017 and 2018, respectively (Figure 6). No MRB adults were collected in the pheromone traps. 


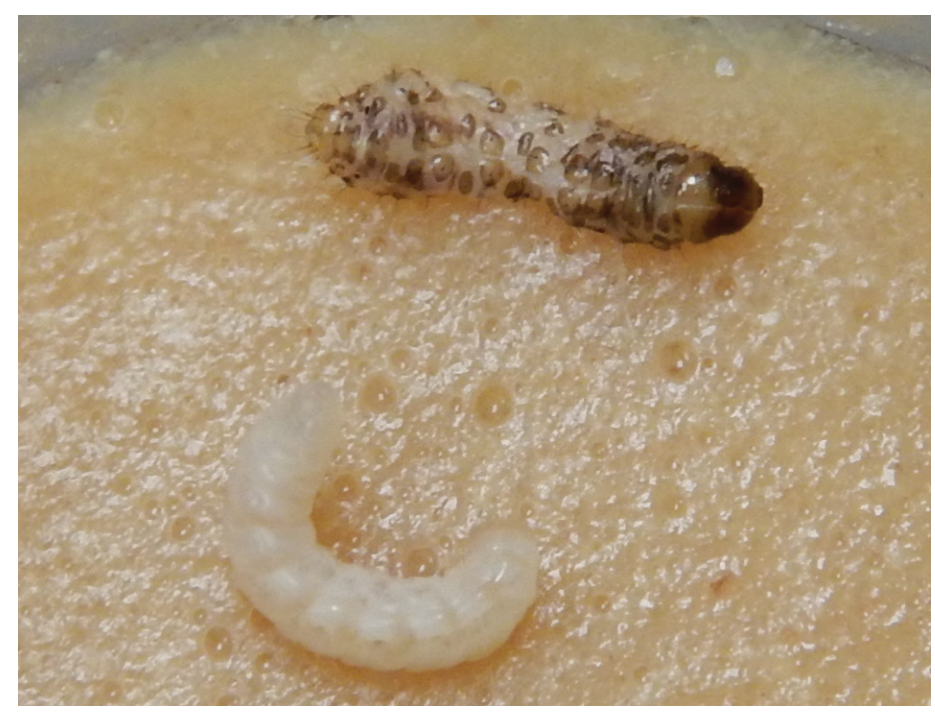

Figure 6. Larva of the parasitic wasp Alabagrus stigma (white, no visible head) after emergence from a parasitized sugarcane borer larva (brown spots, dark brown head capsule).

Credits: Julien Beuzelin, UF/IFAS

\section{Pest Status of Stem Borers in Rice and Recommendations}

Recent observations suggest that the SCB is likely the only stem borer infesting rice in southern Florida (Roldán et al. 2020). In addition, current SCB pest pressure is extremely low in Florida compared to other southern states. In Texas, SCB infestation levels attain 1.0 larva/ $\mathrm{ft}^{2}$, which is 16.5 -fold greater than in the most infested field in this survey. Biological control provided by parasitic wasps might be the main cause for this reduced pest status in Florida rice. Thus, the SCB should not be considered a threat to Florida rice under current production conditions. Although pyrethroid insecticides are registered and effective for stem borer management in rice, these insecticides should not be applied for SCB management in general because of extemely low population levels, and to avoid the disruption of biological control provided by parasitic wasps.

Recent observations suggest that the RSB might not occur in southern Florida and that the MRB has not become established in rice fields of the region. However, geographical range expansion of the MRB toward the Florida rice production area is expected based on observations in Texas and Louisiana, and on the fact that the MRB feeds on numerous non-crop grasses (e.g., johnsongrass). Extension personnel and growers should be aware of the differences between SCB, RSB, and MRB larvae (Figure 1) and should proactively monitor MRB's movement from central Florida to southern Florida using pheromone traps. Early detection of MRB populations in southern Florida will facilitate a timely management response in rice. If suspect MRB moths or larvae are observed, Dr. Julien Beuzelin at the UF/
IFAS Everglades REC (jbeuzelin@ufl.edu) or Dr. Matthew VanWeelden with UF/IFAS Extension Palm Beach County (mvanweel1@ufl.edu) should be contacted.

\section{References}

Beuzelin, J. M., B. E. Wilson, M. T. VanWeelden, A. Mészáros, M. O. Way, M. J. Stout, and T. E. Reagan. 2016. "Biology and Management of the Mexican Rice Borer (Lepidoptera: Crambidae) in Rice in the United States." Journal of Integrated Pest Management 7:7. https://doi. org/10.1093/jipm/pmw006

Beuzelin, J. M., R. H. Cherry, G. S. Nuessly, and H. S. Sandhu. 2019. "Insect Management in Sugarcane." ENY406/IG065. EDIS 2019. https://edis.ifas.ufl.edu/ig065

Bhadha, J., R. Khatiwada, S. Galindo, N. Xu, and J. Capasso. 2018. "Evidence of Soil Health Benefits of Flooded Rice Compared to Fallow Practice." Sustainable Agriculture Research 7:31-41. https://doi.org/10.5539/sar.v7n4p31

Bhadha, J., L. Trotta, and M. T. VanWeelden. 2019. “Trends in Rice Production and Varieties in the Everglades Agricultural Area." SL439/SS653. EDIS 2019. https://edis.ifas.ufl. edu/ss653

Bhadha, J., A. L. Wright, and G. H. Snyder. 2020. "Everglades Agricultural Area Soil Subsidence and Sustainability." SL311/SS523. EDIS 2020 (2) https://doi.org/10.32473/ edis-ss523-2020

Capinera, J. 2016. "Sugarcane borer, Diatraea saccharalis (Fabricius) (Insecta: Lepidoptera: Pyralidae)." EENY217/ IN374. EDIS 2004 (6) https://doi.org/10.32473/ edis-in374-2001

Cherry, R. 2019. “Stink Bugs in Florida Rice.” IG479/ IN1009. EDIS 2019. https://edis.ifas.ufl.edu/in1009

Cherry R., J. Powell, and M. Ulloa. 1994."Reduced Soil Insecticide Use in Sugarcane Planted after Rice." Journal of the American Society of Sugar Cane Technologists 14: 77.

Roldán, E. L., J. M. Beuzelin, M. T. Van Weelden, and R. H. Cherry. 2020. "The Sugarcane Borer (Lepidoptera:Crambidae) Infests Rice at Low Population Levels in Florida." Journal of Economic Entomology 113:538-542. https://doi.org/10.1093/jee/toz255 
VanWeelden, M. T., R. Cherry, and M. Karounos. 2020.

"Relative Abundance of the Stink Bug (Hemiptera:

Pentatomidae) Complex Infesting Rice in the Everglades

Agricultural Area of Florida." Journal of Economic Entomol-

ogy 113:1582-1585. https://doi.org/10.1093/jee/toaa018

Wilson, B. E., J. M. Beuzelin, and T. E. Reagan. 2017.

"Population Distribution and Range Expansion of the Invasive Mexican Rice Borer (Lepidoptera: Crambidae) in Louisiana."Environmental Entomology 46:175-182. https:// doi.org/10.1093/ee/nvx036 